\title{
Hemoglobin $\alpha$ Chain Deficiency in Black Children with Variable Quantities of Hemoglobin Bart's at Birth
}

\author{
C. ALTAY, ${ }^{(30)}$ B. RINGELHANN(31) G. I. YAWSON, A. A. BRUCE-TAGOE, F. I. D. \\ KONOTEY-AHULU, L. JAMES, M. GRAVELY, AND T. H. J. HUISMAN ${ }^{(32)}$ \\ Laboratory of Protein Chemistry and Comprehensive Sickle Cell Center, Medical College of Georgia, Augusta, Georgia, USA; National Institute for \\ Rheumatism, Budapest, Hungary, and Ghana Institute of Clinical Genetics, Accra, Ghana
}

Summary

Hematologic and globin chain synthesis studies have been made in 21 children, aged 2 to 6 years, many of their parents, and several normal adults and $\alpha$-thalassemia heterozygotes. At birth, 11 children had about $5 \%$ hemoglobin (Hb) Bart's, 5 had about $2 \% \mathrm{Hb}$ Bart's, and 5 had no trace of $\mathrm{Hb}$ Bart's. A significant decrease in mean corpuscular volume. (MCV) and mean corpuscular hemoglobin (MCH) values and an increase in the $\beta / \alpha$ ratio was observed in the first group; microcytosis and hypochromia were absent in the children of the second group although the $\beta / \alpha$ ratio was significantly increased. The $\alpha$ chain deficiency is familial. Increased $\alpha / \alpha$ ratios were present in many parents although only two parents of children with $5 \% \mathrm{Hb}$ Bart's at birth had hematologic findings suggestive of the presence of the same type of defect as observed in the children with the larger amount of $\mathrm{Hb}$ Bart's at birth.

\section{Speculation}

It is postulated that the absence or presence of duplicated $\mathrm{Hb}_{\alpha}$ structural genes is the underlying mechanism for the variable $\alpha$ chain deficiency in black infants. Children with about $5 \%$ Hb Bart's at birth have the genotype $-\alpha /-\alpha$ or, rarely, the $--\mid \alpha \alpha$ genotype; when only two $\mathrm{Hb}_{\alpha}$ structural loci instead of four are active, a modest deficiency in $\alpha$ chain production will be the result. The presence of the $-\alpha / \alpha \alpha$ genotype could be predicted from the smaH amounts of $\mathrm{Hb}$ Bart's at birth and from data of the hemoglobin synthesis analyses in older children and adults; the $-\alpha / \alpha$ genotype however, is also suggested from data obtained by $\mathrm{MCH}$ and MCV determinations. It is concluded that although the $-\alpha / \alpha$ genotype always produces Hb Bart's at birth in moderate amounts, the $-\alpha / \alpha \alpha$ genotype may or may not. The rarity of the $--/ \alpha \alpha$ genotype in this population is responsible for the absence of the Hb Bart's hydrops fetalis syndrome. 
INTRODUCTION

The presence of Hb Bart's or $\gamma_{4}$ in blood of newborn bables is regarded as an indication for some form of a chain deficiency which ia of ten termed athalassemia (for a review and references see (28)). The expression of this
type of deficlency includes extremes; for instance, a total $\alpha$ chan deficlency type of deficlency includes extremes; for fnstance, a total a chain deficlency exists in the infant with hydrops fetalls whereas others appear clinically and
hematologically norma 1 . The various forms of a-thalassemia (discussed in (28) can best be differentiated by the relative amounts of Hb Bart's at birth. In the Far East, $\alpha$-thalassemia-1 is recognized because it 18 associated with complete suppression of the a chain synthesis and a-thalassemia-2 is associated conditions and a double heterozygosity contribute to the heterogeneity of the condit ions and a double heterozygosit

Hib Bart's has also been found in blood from Black newborns $(5,7,8,9,10$ and others) and in newborns from various other racial and/or ethnic origin Buch as Saudia Arabia (22), Cuba (19), Malaya (18) (see also Table I of ref. 5). about $5 z$ of Nigerian newborns had $\mathrm{Hb}$ Bart's and a comparable incidence has bee observed in others. The quantities of Hb Bart's vary considerably which, at least in part, can be explained by differences in methods used for quantitatio
However, the amount does not exceed $10 \mathrm{z}$, and $\mathrm{Hb} \mathrm{H}$ disease and hydrops fetalis have never been found among African Blacks. Some invest1gators $(7,8,10,27)$ suggest that the presence of Hb Bart's indicates an inherited a chain deficlency (although a previous limited study by one of the present authors (10) did not substantiate this hypothesis) but others (5) believe that 1ts occurrence fo a developmental abnormality.

A survey of 14,053 newborns which was conducted by one of the authors over a period of 15 years (13) showed that 366 (or 2.65x) had moderate amounts of Hb Bart's, (1ater to be def 1ned as the "ch1ldren with $5 x$ Hb Bart's") whereas 1330 bables (9.45z) had swall amounts of Hb Bart's (the children with less comparable to quent communication, we describe data on 21 Black children, aged 2 to 6 years, who had variable amounts of Hb Bart's (from zero to 5z) at birth using both hematological and in vitro globin cha1n synthesis studies. In order to further evaluate the significance of the Hb Bart's anomaly In the newborn period, many
of the parents of the che children were also studied. The data are interpreted of the parents of these children were also studied. The data are interpreted
to indicate the presence of elther single or duplicated $\mathrm{Hb}_{\alpha}$ chaln loci on one to indicate the present
or both chromosomes.

\section{MATER IALS AND METHODS}

\section{Chlldren and Adults Participating in the Study}

Fifteen Black children frow the Augusta area were selected from a roster of cases who had been tested in 1973 and 1974 by one of the authors (T.H.J.H.) for the possible presence of Hb Bart's and other hemoglobin variants. Five
ch1ldren, aged 19-36 months, had about 5\% Hb Bart's at b1rth, five, aged 24-37 children, aged 19-36 months, had about $52 \mathrm{Hb}$ Bart's at b1rth, five, aged 24-37
months, had 1-2Z Hb Bart's at birth, while five, aged $21-24$ months, had no
Hb Bart's. Quantitation of Hb Bart's at that time was based in part on the visual inspection of a starch gel block stained with o-dianisidine (3) and on data obtained by column chromatography using the cation exchanger CM-cellulos (14). The variability in the amounts of Hb Bart's has been described befor (10): the group referred to in that study as having "small quantitles of "maderate amounts of Hb Bart's" will be termed "children w1th $5 z$ Hb Bart's." "moderate amounts of Hb Bart's" will be termed "chlldren with $5 z$ Hb Bart's;" zone 1solated by column chromatography was of ten contaminated with small amount $B$ of other hemoglobins such as the minor $\mathrm{Hb} F_{1}$ and $\mathrm{Hb} A_{1}$ components. amount 8 of other hemoglobins such as the minor Hb $F_{1}$ and $\mathrm{Hb} A_{1}$ components.
Methods to improve the quantitation of $\mathrm{Hb} B a r t ' s$ are presently under study; however, 1t appears that the amount of $\mathrm{Hb}$ Bart's in newborns of the "2z $\mathrm{Hb}$ Bart's" group varies between 17 and $2 z$, and that in newborns of the "5Z Hb Bart' $s$ " group between $3.5 \%$ and $7 \pi$ (14). Parents of the 10 children with $\mathrm{Hb}$

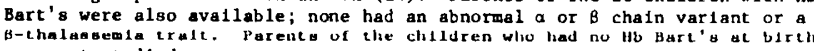
were not atudied.

A fourth group of chlldren were studied in Ghana in 1974. These 6 children were found to have 4 to $6 \% \mathrm{Hb}^{\mathrm{Bart}} \mathrm{C} \mathrm{s}$ at $\mathrm{t}$ ime of birth, and were reinvestigated at the age of about 4 years together with their mothers. Two children
were also heterozygous for $\mathrm{Hb} S$, and one for $\mathrm{Hb} \mathrm{C}$, while three mothers had a were also heterozygous
$\mathrm{Hb} S$ heterozygo日tty.

Eight healthy Caucasian adults and 14 healthy Black adults (mostly laboratory workers and the1r relatives) served as control groups. In addition, 5 persons with a definite a thalassemla tratt were also avallable. One was a
Black female described before (20), and the others were of Greek or Chinese Black female described before $(20)$, and the other
descent and related to persons with $\mathrm{Hb}$ idisease.

Hematological and Hemoglobin Studieg

Blood samples were collected in vacutalners and elther transported in ice to the laboratory or studied in part at the home of the donor. Hematological measurement 8 were made with a Coulter Counter model $S$ electronic cell counter.
Other hematological determinations were made by standard methods (29). Red Other hematological determinat ions were made by standard methods (29). Red
cell hemolysates were prepared as described before (4) and analyzed by starch gel electrophoresis for the detection of abnormal hemoglobin (3), by microcol umn chromatography for the quantitation of $\mathrm{Hb} \mathrm{A}_{2}$ (12) and by an alkali denaturation procedure for the quantitation of $\mathrm{Hb} F(1)$. Hemoglobins $\mathrm{S}$ and $\mathrm{C}$

\section{Hemoglobin Synthes1s Studies}

Globin synthesis determinations were made by the method of Friedman et al (6) as modiffed in our own laboratory (13). Way method of Friedman et a locytes by fractional centrifugation, were incubated for 120 minutes with ${ }^{14} \mathrm{C}$ leucine in an appropriate medium elther in the home of the donor or soon afte arrival in the laboratory (13). Separation of the a and $B$ chains was made by
column chromatography, and the $B / \alpha$ ratio was calculated using the total radiocolumn chromatography, and the $B / \alpha$ ratio was calculated using the total radio-
activity present in the chromatographic fractions corresponding to each of the
hemoglobin chains.

\section{Stat 1st1cal Studies}

The significance of the differences between two mean values was assessed by the Student " $t$ " test.

\section{RESULTS}

\section{Hematologic and Hemoglobin Studies}

Starch gel electrophoretic examination showed that none of the children from Georgia who had Hb Bart's at birth had any hemoglobin variant at the
time of examination; notably, no trace of $\mathrm{Hb} H$ or Hb Bart's was detectable.
The same was true for the chlldren from Ghana except that 3 were heterozygous for a $B$ chain variant.

A summary of the most pertinent hematological data is given in Table $I_{i}$ Tables II, III, and IV which are part of the addendum to this paper give detalls on the individual cases. Serum fron levels were normal although in 2
ch1ldren the level ( $10 \mu$ mol/1) was in the low range of our normal values ( $9-30$ $\mu$ mol/1). Similar data were not ava1lable for the children from Ghana. Bthalassemia was absent and the level of $H b F$ (as $F$ F) was less than $2 Z$ in all

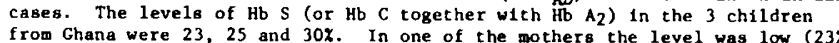
from Ghana were 23,25 and $30 \%$. In one of the mothers the level was low (23z)
and $1 n$ two the leve 18 were 31 and $32 z$. Examination of peripheral blood smears and $1 \mathrm{n}$ two the leve1s were 31 and $32 \mathrm{~s}$. Examination of peripheral blood smears
showed a mild hypochromia, an1socytosis and polk1locytosis in all children who showed a mild hypochromia, an1socytosis and polkilocytosis in all children who
had $5 \% \mathrm{Hb}$ Bart's at b1rth, In two of the1r parents, and in all 5 subjects with had $5 \%$ Hb Bart's at birth, In two of their pare
a thalassemia trait. Fig. I gives an example.

Most significant were the differences in the MCV and MCH values and the B/a synthetic ratios. The Individual data for the children from Georgia, their parents, and the persons serving as adult controls are plotted in Figures 2 and Hb Bart's was comparable to that found hypochromia in the ch1ldren with $5 x$ tralt. The microcytosis and hypochromla were absent in the children of the $2 x$
the Hb Bart's group; their values were not different from those found for the 5 Hb Bart 's group; their values were not different from those found for the 5
children of the $0 x$ Hb Bart's group. The parents of the " $5 \mathrm{z}$ Hb Bart's" children children of the $0 Z$ Hb Bart's group. The parents of the "5Z hb Bart's" childre
showed a wide range in MCV and MCH values; two persons (the father of child II showed a wide range in MCV and MCH values; two persons (the father of child II
and the mother of child III) had a marked hypochromis and microcytosis. The and the mother of child III) had a marked hypochromis and microcytosis. The
values for the parents of the children with the $2 \%$ Hb Bart's fell in the range of normal and were not different from the data found in the persons who served as controls.

\section{Hemoglobin Synthesis Studies}

The results of the in vitro biosynthet1c analyses (Fig. 3) again indicate algnificant differences between the varlous groups. A distinct a chain deficlency was evident for all 5 children with $5 \%$ Hb Bart's (average $B / \alpha$ rat 10

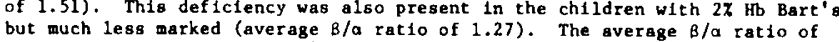
but much less marked (average $B / a$ ratio of 1.27 ). The average $B / \alpha$ ratio of the children without Hb Bart's showed a balanced chain synthesis; however, at
least in one child a mild $\alpha$ chain deficiency is apparent. The majority of the parents of the children with the $5 \%$ and the $2 \pi$ Hb Bart's showed a mild $\alpha$ chain deficfency (the $B / a$ rat 10 in 14 of the 18 persons with acceptable results fell between 1.2 and 1.5), 2 parents (both of children of the $57 \mathrm{Hb}$ Bart's group and both having a distinct microcytosis and hypochromia) had an overt a chain
deficlency, and 2 had a balanced chain synthesis. The B/a rat los of the 5 persons with the a-thalassemla tralt were higher with the exception of a ratio

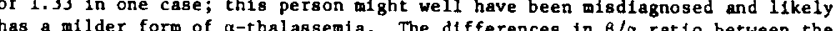
has a milder form of $\alpha$-thalassemia. The differences in $\beta / \alpha$ ratio between the Black and Caucasian adults, although statist1cally not significant, are of
interest; it appears that 5 of the 14 Black controls had a mild $\alpha$ chain deficiency with a $B / \alpha$ rat 10 ranging between 1.17 and 1.35 .

\section{Stat18t1cal Studies}

Statistical anslyses of all data are presented in Table $V$ of the Addendum DISCUSSION

The data obtained in this study indicate that an a chain deficiency is the underlying cause for the presence of Hb Bart's that is present in some Black chlldren at birth. This deficlency persists throughout life, is genetically Friedman et al 18 not a developmental abnormality as suggested by Esan (5). data, globin synthesis ratios, and $\alpha$ chain pool studies indicate that Black infants with greater than $2 z$ Hb Bart's have $\alpha-$ thalassemia" (7). The aynthesis of adult hemogichin $1 \mathrm{~s}$ undur the control of genes for the
$\alpha$ cha1n and for the $\beta$ production. Lehmann $(16,17)$ has proposed that the $\alpha$ chain gene in man can be duplicated, and results from studies on persons with abnormal a chain variants (for references and review see (20)) have indicated that multiple $\alpha$ chain loci do occur in some populations but not in all. The
genetic heterogeneity of $\alpha$ chain deficiency (or $\alpha$-thalassemia) therefore can also be explained on the basis that production of a chains depends upon control by duplicated a chain gene loc1, aa/aa (26). The absence or the lack of function of from one to all four genes would account for all the different phenotypes $(17,26)$. Thus, the two types of a thalassemia trait (a thalassemia 1 and a thalassemia-2) can be considered to represent the genotypes --/aa and drome that of the enotype $--/--$ genotpye $--/-\alpha$ and the hydrops fetal1s synhybridization studies $(15,21,24)$ indicating that $\alpha$ chain supported by data from some of these conditions.

This concept allows two genotypes for an Individual with abnormalities characteristic for $\alpha$ thalassemia-1 trait, namely --/aa and $-\alpha /-\alpha$. In both, only two active $\alpha$ chaln atructural loci are present. Parents with the -laa genotype will have a 1 in 4 chance of having an of spring with genotype $-1--$, $i . e$. a baby with hydrops fetal1s; however, such a baby will not be born to parents with genotype $-\alpha /-a$. Assuming an Incidence of about $2.5 \%$ of a thaltion of Georgia (13) and considering the fact that the fetalis syndrome with genotype --/-- is absent in this Black population on has to assume that the $-\alpha /-a$ genotype is the major genotype causing a def 1 clency in a chain production. Thus, the presence of genotype $-\alpha /-\alpha$ results in the presence of about $5 \pi \mathrm{Hb}$ Bart's at b1rth, in a persistant $\alpha$ chain deficiency with $B / \alpha$ rat 10 s averaging about 1.5 and with a modest hypochromia and microcytosis. The $-\alpha / \alpha$ a genotype is responstble for the presence of much smaller amounts of Hb Bart's at birth (perhaps some bables with this genotype do not produce any Hb Bart's at all), for a most modest $\alpha$ chaln deficiency with an
average $B / a$ ratio of about 1.25 without average $8 / a$ ratio of about 1.25 without significant microcytosis and hypochro-
mia. It of ten appears difficult to distinguigh between the expression of genomia. It of ten appears difficult to distingulah between the expression of geno-
types $-\alpha / \alpha a$ and $a / \alpha a$; bables with the latter do not have an $a$ chain deficiency.

Based on these assumptions, one is able to assign a specific genotype to the individuals who participated in this study (Table $I 1$ of the Addendun). specific alws possible to decide with reasonable conflence between specific genotypes; moreover, the presence of genotype --/aa cannot be excluded with persons of Aslan origin (see also 20).

The pedigrees of Fig. 4 1llustrate again the familial aspects of the chain deficlency (the data are from Table III; famlly $X$ refers to the fifth family of the group of children with $5 \%$ Hb Bart's and Family $Y$ to the first farily of the group with $2 \%$ Hb Bart's). The parents in Family $X$ have a mild a chaln deficiency but their child has a $B / a$ chain ratio of 1 . So with a $\mathrm{d} / \mathrm{s}-$ figure. The presence of $-\alpha / \alpha a$ genotype in both parents of Family $Y$ (despite 
a h1gh B/a ratio of 1.49 in the mother) is supported by two different genotypes observed in the offspring. These data and the hematological findings clearly Indicate that while the $-\alpha / \alpha a$ genotype does not produce significant hemato gical abnormalities, the $-a /-a$ type 1 s not only detectable by an 1 .
in vitro synthesis ratio but also by decreased MCH and MCV values.

The results of these studies also explain the rather wide variability in $B / a$ chain synthesis ratios observed in normal (Black) controls. The presence B/a chain synthesis ratios observed in normal (Black) controls. The presence in a refle not al ays critically evaluated) is 11kely responsible for the $\beta / \alpha$ ratios not always crit $1.2(33,34)$.

\section{REFERENCES}

1. Betke, K., Marti, H. R. and Schllcht, I.: Estimation of small percentages of foetal haemoglobin. Nature, 184: 1877, 1959

2. Dozy, A. M., Klethauer, E. F. and Hulsman, T.H.J.: Studies on the heter ogene1ty of hemoglobins. XIII. Chromatography of various human and animal hemoglobin types on DEAE-Sephadex. J. Chromatogr., 32: 723 , 1968 .

3. Ef remov, G. D., Kulsman, T.H.J., Smith, L. L., Wilson, J. B., Kitchens, J. L., Wrighstone, R. N. and Adams, H. R.: Hemoglobin Richmond, a huma hemoglobin which forms asymetric hybrids with other hemoglobins. J. B1o1. Chem 244: 6105, 1969 .

4. Ef remov, G. D. and Hulsman, T.H.J.: The laboratory diagnosis of hemoglobinopathies. Clin. In Hematol., 3: 527, 1974.

5. Esan, G.J.F.: Haemogiobin Bart's in newborn Nigerian. Brit. J. 1: Haematol. 22: 73,1972 .

6. Friedman, S., Hamiliton, R. W. and Schwartz, E.: B-thalassemia in the American Negro. J. Clin. Invest., 52: 1453, 1973.

American Negro. J. C11n. Invest., 52: 14S3, 1973. in Negro Infants. Pediat. Res., 8: $955,1974$.

8. Henrickse, R. G., Boyo, A. E., Fitzgerald, P. A, and Ransome Kut1, S. Studles on the haemoglobins of newborn Nigerians. Brit. Med. J., : 611,1960 .

9. Honig, G. R., Gunay, U., Mason, R. G., Vida, L. N. and Ferenc, C.: Sickle cell syndromes. I. Hemoglobin SC- $\alpha$-thalassemla. Pediat. Res. 10: 613, 1976 .

10. Horton, B. F., Thompson, R. B., Dozy, A. M., Nechtman, C. M., N1chols, E. and Hulsman, T.H.J.: Inhomogeneity of hemoglobin. VI. The minor hemoglobin components of cord blood. Blood, 20: 302, 1962.

11. Hu1sman, T.H.J. and Dozy, A. M.: Studies on the heterogenelty of hemoglobin. IX. The use of tris (hydroxymethyl) aminoethane HCl buffers in the anion exchange chromatography of hemoglobins. J. Chromatogr. 19: 160,1965

12. Huisman, T.H.J., Schroeder, W. A., Brodie, A. R., Mayson, S. M. and Jakway, J.: Microchromatography of hemoglobins. III. A simplifled procedure for the determination of hemoglobin $A_{2}$. J, Lab. Clin. Med. 80: 700,1975 .

13. Hulsman, T.H.J. and Jonx1s, J.H.P.: The Hemoglobinopathies, Techniques of Identification. Marcel Dekker Inc., New York, in press.

(K.H.: Unpublished observation

Kan, Y. W., Dozy, A. M., Varmus, H. E., Taylor, J. M., Holland, J. P., Lie-Injo, L. E., Ganesan, J. and Todd, D.: Deletion of $\alpha-g$ lobin genes In haemoglobin H disease

16. Lehmann, 4 , and Carrell, R. W.: Differences between $\alpha$ - and $\beta$-chain mutants of human haemoglobin and between $\alpha$ - and $\beta$-thalassemia. Possible duplication of the $\alpha$-chain gene. Brit. Med. J., 4: 748, 1968.

17. Lehmann, H.: Different types of alpha-thalassemia and significance of haemoglob1n Bart's in neonates. Lancet, 2: 78, 1970.

18. Lie-Injo, L. E. and Ti, T.S.: The fast moving haemoglobin component in healthy newborn babies in Malaya. Med. J. Malaya, 16: 107, 1961.

19. Martinez, G., and Colombo, B.: $\alpha$-Thalassemia in Cuba. Acta Haemato1. 55: $36,1976$.

20. Milner, P. F. and Huisman, T.H.J.: Studies on the proportion and synthesis of haemoglobin G-Philadelphia in red cells of heterozygotes, a homozygote, and a heterozygote for both haemoglobin $G_{\alpha}$ and $\alpha$-thalassemia. Brit. J. Haematol. 34: 207, 1976.

21. Ottolenghi, S., Lanyon, w. G., Paul, J., Williamson, R., weatherall, D.J., Clegg, J. B. Pritchard, J., Pootrakul, S, and Wong, H. B.: Gene deletion as the cause of $\alpha$-thalassemia. Nature, 251: 389, 1974 .

22. Penbrey, M. E., Weatherall, D. J., Clegg, J. B., Bunch, C., and Perrine, R. P.: Haemoglobin Bart's in Saudi Arabia. Brit. J. Haematol., 29: 221,1975

23. Pootrakul, S., Sapprapa, S., Wasi, P., Na-Nakorn, S., and Suwanik, R.: Haemoglobin synthesis in 28 obligatory cases for $\alpha$-thalassemia traits. 121, 1975

24. Taylor, J. M. Dozy, A. M. Kan, Y. W., Varmus, H. E., Lie-Injo, L. E. Ganesan, J., and Todd, D.: Genetic lesion in homozygous $\alpha$-thalassemia (hydrops fetalis). Nature, $251,392,1974$.

25. Wasi, P.: The alpha thalassemia genes. J. Med. Ass. Thailand, 53:677, 1970 .

26. Wasi, P., Na-Nakorn, S. and Pootrakul, S.: The $\alpha$-thalassemia. Clin. in Haematol., 3: 383,1974 .

27. Weatherall, D. J.: Abnormal haemoglobins in the neonatal period and their relationship to thalassemia. Brit. J. Haematol., 9. 265, 1963. weatherall, D. J., and Clegg, J. B.: The thalassemia syndromes.

Blackwell Scientific Publications, Oxford, 1972.

29. wintrobe, M. M., Lee, G. R., Boggs, D. R., Bithell, T. C., Athens, J. W. and Foerster, J.: Clinical Hematology, Ed. 7, Lea and Febiger, Philadelphia, Pa., USA, 1974.

30. On leave from the Department of Pediatrics, Hacettepe University, Ankara, Turkey.

31. Dr. Ringelhann was, in part, responsible for the studies conducted in Ghana while temporarily stationed in that country.

32. Correspondence and request for reprints should be addressed to Dr. T.H.J. Huisman, Laboratory of Protein Chemistry, Medical College of Georgia, Auqusta, GA 30902, USA.

33. Informed consent was obtained for all subjects in this study.

34. Supported in part by U. S. Public Health Service Research Grants $\mathrm{HL}-05168$, and $\mathrm{HL}-15158$.

TABLE I. The mean values, standard deviations, and ranges of some hematological findings.

\begin{tabular}{|c|c|c|c|c|c|}
\hline Subject & $\begin{array}{c}\text { Age ln } \\
\text { mos. and } \\
\text { (no. of cases) }\end{array}$ & $\begin{array}{l}\mathrm{Hb} \\
\mathrm{g} / \mathrm{d} 1\end{array}$ & $\begin{array}{c}\mathrm{RBC} \\
10^{12} / 1\end{array}$ & & $\begin{array}{l}\mathrm{PCV} \\
1 / 1\end{array}$ \\
\hline $\begin{array}{l}\text { Children with } \\
\text { Sz Hb Bart's }\end{array}$ & $\begin{array}{c}28 \pm 6.2 \\
(S)\end{array}$ & $\begin{aligned} 11.64 & \pm 1.52 \\
(9.6 & -13.6)\end{aligned}$ & $\begin{array}{c}5.39 \pm 0.51 \\
(4.58-5.66)\end{array}$ & $\begin{array}{r}0.333 \\
(0.290\end{array}$ & $\begin{array}{l} \pm 0.03 \\
-0.376)\end{array}$ \\
\hline $\begin{array}{l}\text { Ch1ldren with } \\
2 \pi \text { Hb Bart's }\end{array}$ & $31 \pm 5.4$ & $\begin{array}{l}12.34 \pm 0.89 \\
(10.9-13.3)\end{array}$ & $\begin{array}{c}4.55 \pm 0.27 \\
(4.24-4.85)\end{array}$ & $\begin{array}{r}0.362 \\
(0.337\end{array}$ & $\begin{array}{l} \pm 0.02 \\
-0.377)\end{array}$ \\
\hline $\begin{array}{l}\text { Children from Ghana } \\
\text { with } 5 \% \text { Hb Bart's }\end{array}$ & $\begin{array}{l}48 \\
(6)\end{array}$ & $\begin{array}{l}10.78 \pm 0.29 \\
(10.4-11.1)\end{array}$ & $\begin{array}{c}5.14 \pm 0.42 \\
(4.65-5.75)\end{array}$ & $\begin{array}{r}0.356 \\
(0.345\end{array}$ & $\begin{array}{l} \pm 0.01 \\
-0.370)\end{array}$ \\
\hline $\begin{array}{l}\text { Children without } \\
\text { Hb Bart's }\end{array}$ & $23 \pm 1.4$ & $\begin{array}{l}12.58 \pm 1.12 \\
(11.3-14.2)\end{array}$ & $\begin{array}{c}4.59 \pm 0.54 \\
(4.00-5.20)\end{array}$ & $\begin{array}{r}0.357 \\
0.333\end{array}$ & $\begin{array}{l} \pm 0.03 \\
-0.400)\end{array}$ \\
\hline $\begin{array}{l}\text { Parents of children } \\
\text { with 5X Hb Bart's }\end{array}$ & $\overline{(10)}$ & $\begin{array}{l}13.40 \pm 1.89 \\
(10.9-16.9)\end{array}$ & $\begin{array}{c}4.90 \pm 0.56 \\
(3.89-5.28)\end{array}$ & $\begin{array}{r}0.394 \\
(0.320\end{array}$ & $\begin{array}{l} \pm 0.05 \\
-0.464)\end{array}$ \\
\hline $\begin{array}{l}\text { Parents of children } \\
\text { w1th } 2 X \mathrm{Hb} \mathrm{Bart} s\end{array}$ & $\overline{(9)}$ & $\begin{array}{l}14.41 \pm 1.90 \\
(11.9-17.4)\end{array}$ & $\begin{array}{c}4.65 \pm 0.48 \\
(4.01-5.59)\end{array}$ & $\begin{array}{r}0.419 \\
0.360\end{array}$ & $\begin{array}{l} \pm 0.05 \\
-0.481)\end{array}$ \\
\hline $\begin{array}{l}\text { Mothers of children } \\
\text { from Ghana }\end{array}$ & - & $\begin{array}{l}11.73 \pm 1.13 \\
(10.2-13.3)\end{array}$ & $\begin{array}{c}4.12 \pm 0.50 \\
(3.57-4.98)\end{array}$ & $\begin{array}{r}0.378 \\
(0.330\end{array}$ & $\begin{array}{l} \pm 0.05 \\
-0.445)\end{array}$ \\
\hline Caucasian Adults & (8) & $\begin{array}{l}14.04 \pm 2.00 \\
(10.6-16.2)\end{array}$ & $\begin{array}{c}4.68 \pm 0.65 \\
(3.38-5.61)\end{array}$ & $\begin{array}{r}0.415 \\
(0.311\end{array}$ & $\begin{array}{l} \pm 0.06 \\
-0.500)\end{array}$ \\
\hline Black Adults & $\overline{(14)}$ & $\begin{array}{l}12.99 \pm 1.56 \\
(10.3-15.1)\end{array}$ & $\begin{array}{c}4.38 \pm 0.54 \\
(3.64-5.76)\end{array}$ & $\begin{array}{r}0.380 \\
(0.201\end{array}$ & $\begin{array}{l} \pm 0.04 \\
-0.461)\end{array}$ \\
\hline Adults with $\alpha$-thal. trait & $\overline{(5)}$ & $\begin{array}{l}12.00 \pm 1.59 \\
(10.8-14.8)\end{array}$ & $\begin{array}{c}5.20 \pm 0.86 \\
(4.56-6.71)\end{array}$ & $\begin{array}{r}0.379 \\
(0.335\end{array}$ & $\begin{array}{l} \pm 0.04 \\
-0.442)\end{array}$ \\
\hline
\end{tabular}




\begin{tabular}{|c|c|c|c|c|}
\hline Subject & $\begin{array}{r}\text { MCV } \\
\mathrm{f} 1\end{array}$ & $\begin{array}{r}\mathrm{MCH} \\
\mathrm{PB}\end{array}$ & $\begin{array}{l}\mathrm{MCHC} \\
\mathrm{g} / \mathrm{d} 1\end{array}$ & $\begin{array}{l}\text { Hb Synthesis } \\
\text { non- } \alpha / a\end{array}$ \\
\hline $\begin{array}{l}\text { Ch11dren with } \\
5 \% \mathrm{Hb} \text { Bart's }\end{array}$ & $\begin{array}{r}63.6 \pm 3.2 \\
(60-67)\end{array}$ & $\begin{array}{l}22.02 \pm 1.36 \\
(20.6-23.8)\end{array}$ & $\begin{array}{c}35.1 \pm 1.50 \\
(33.5-36.9)\end{array}$ & $\begin{array}{l}1.514 \pm 0.096 \\
(1.40-1.63)\end{array}$ \\
\hline $\begin{array}{l}\text { Children with } \\
22 \text { Hb Bart's }\end{array}$ & $\begin{array}{l}79 \pm 2.12 \\
(77-82)\end{array}$ & $\begin{array}{l}26.68 \pm 1.59 \\
(25.1-28.9)\end{array}$ & $\begin{array}{l}34.24 \pm 1.85 \\
(32.4-35.8)\end{array}$ & $\begin{array}{r}1.27 \pm 0.070 \\
(1.20-1.36)\end{array}$ \\
\hline $\begin{array}{l}\text { Children from Ghana } \\
\text { with } 5 \% \text { Hb Bart's }\end{array}$ & $\begin{array}{c}68.4 \pm 5.68 \\
(60-75)\end{array}$ & $\begin{array}{l}21.25 \pm 1.64 \\
(18.5-23)\end{array}$ & $\begin{array}{l}30.67 \pm 0.26 \\
(30.5-31.0)\end{array}$ & $\begin{array}{r}1.47 \pm 0.234 \\
(1.20-1.90)\end{array}$ \\
\hline $\begin{array}{l}\text { Children without } \\
\text { Hb Bart's }\end{array}$ & $\begin{array}{l}78 \pm 4.95 \\
(74-86)\end{array}$ & $\begin{array}{l}27.12 \pm 2.05 \\
(25.1-30.5)\end{array}$ & $\begin{array}{c}35.2 \pm 1.41 \\
(33.3-37.0)\end{array}$ & $\begin{array}{r}1.07 \pm 0.149 \\
(0.86-1.26)\end{array}$ \\
\hline $\begin{array}{l}\text { Parents of ch1ldren } \\
\text { with } 5 \% \mathrm{Hb} \text { Bart's }\end{array}$ & $\begin{aligned} 79.5 & \pm 6.88 \\
(66 & -89)\end{aligned}$ & $\begin{array}{l}27.02 \pm 3.12 \\
(21.6-32.2)\end{array}$ & $\begin{array}{l}34.29 \pm 1.39 \\
(32.6-36.6)\end{array}$ & $\begin{array}{l}1.379 \pm 0.267 \\
(1.10-1.84)\end{array}$ \\
\hline $\begin{array}{l}\text { Parents of children } \\
\text { with } 22 \text { Hb Bart's }\end{array}$ & $\begin{aligned} 89 & \pm 4.69 \\
(85 & -98)\end{aligned}$ & $\begin{array}{c}30.5 \pm 2.19 \\
(28.3-35.6)\end{array}$ & $\begin{array}{l}34.50 \pm 1.71 \\
(32.3-36.9)\end{array}$ & $\begin{aligned} & 1.28 \pm 0.152 \\
&(0.94-1.49)\end{aligned}$ \\
\hline $\begin{array}{l}\text { Mothers of children } \\
\text { from Ghana }\end{array}$ & $\begin{array}{l}91 \pm 5.29 \\
(85-98)\end{array}$ & $\begin{aligned} 29 & \pm 1.82 \\
(27 & -31)\end{aligned}$ & $\begin{array}{l}31 \pm 1.82 \\
(30-35)\end{array}$ & $\begin{array}{l}1.127 \pm 0.259 \\
(0.84-1.43)\end{array}$ \\
\hline Caucaslan Adulta & $\begin{array}{l}89 \pm 5.70 \\
(79-98)\end{array}$ & $\begin{array}{l}29.85 \pm 2.05 \\
(26.4-31.6)\end{array}$ & $\begin{array}{l}33.60 \pm 2.04 \\
(29.0-35.3)\end{array}$ & $\begin{array}{l}1.038 \pm 0.10 \\
(0.88-1.18)\end{array}$ \\
\hline Black Adult B & $\begin{array}{c}86.86 \pm 5.03 \\
(78-95)\end{array}$ & $\begin{array}{l}29.71 \pm 1.72 \\
(27.2-32.1)\end{array}$ & $\begin{array}{l}34.51 \pm 1.05 \\
(32.0-36.8)\end{array}$ & $\begin{aligned} 1.11 & \pm 0.121 \\
(0.99 & -1.35)\end{aligned}$ \\
\hline Adults with $\alpha$-thal. tralt & $\begin{aligned} 72.8 & \pm 0.83 \\
(65 & -76)\end{aligned}$ & $\begin{aligned} 23 & \pm 0.83 \\
(21.7 & -24)\end{aligned}$ & $\begin{array}{l}31.82 \pm 1.25 \\
(30.4-33.7)\end{array}$ & $\begin{array}{r}1.65 \pm 0.202 \\
(1.33-1.87)\end{array}$ \\
\hline
\end{tabular}

ADDENDUM

Th1s addendum consists of four tables, as follows: Table II presents the data collected on each of the Black children and their parents. Table III gives similar data on the children studied in Ghana and their mothers while comparable data on normal Caucaslan and Black adult $s$ and on the five $\alpha$ thalassemia heterozygotes are listed in Table IV. Detalled statistica analyses are given in Table $V$.

TABLE II Hematological and Hemoglobin Synthesis Data on children and their parents.

\begin{tabular}{|c|c|c|c|c|c|c|c|c|c|c|c|c|}
\hline Subjects ${ }^{\star}$ & $\begin{array}{c}\mathrm{RBC} \\
10^{12} / 1\end{array}$ & $\begin{array}{c}\mathrm{Hb} \\
\mathrm{g} / \mathrm{d} 1\end{array}$ & $\begin{array}{l}\mathrm{PCV} \\
1 / 1\end{array}$ & $\begin{array}{r}\text { MCV } \\
f 1\end{array}$ & $\begin{array}{r}\mathrm{MCH} \\
\mathrm{Pg}\end{array}$ & $\begin{array}{l}\mathrm{MCHC} \\
8 / \mathrm{d} 1\end{array}$ & $\begin{array}{c}\mathrm{Fe}^{\star \star} \\
\mu \mathrm{mol} 1 / 1\end{array}$ & $\begin{array}{c}\mathrm{TIBC} \\
\mu \mathrm{mol} / 1\end{array}$ & $\begin{array}{l}\text { Suggested } \\
\text { Genotype }\end{array}$ & \multicolumn{3}{|c|}{$\frac{\text { HEMOGLOB IN SYNTHESIS }}{\text { Total Count }}$} \\
\hline \multirow{2}{*}{\multicolumn{13}{|c|}{ Children w1th $5 z$ wb Bart's and their parents. }} \\
\hline & & & & & & & & & & & & \\
\hline$M-36$ & 5.39 & 12.3 & 0.340 & 62 & 22.5 & 36.9 & 13 & 80 & $-\alpha /-\alpha$ & 739 & 466 & 1.59 \\
\hline Mother & 4.55 & 12.5 & 0.360 & 78 & 27 & 35.2 & 13 & 59 & $-\alpha /-\alpha$ & 1230 & 878 & 1.40 \\
\hline Father & 5.28 & 14.2 & 0.430 & 81 & 26.5 & 33.2 & 19 & 69 & $-\alpha /-\alpha$ & 2286 & 1826 & $5 \quad 1.25$ \\
\hline II- $\quad F-19$ & 4.70 & 10.8 & 0.320 & 67 & 22.5 & 33.9 & 13 & \multicolumn{2}{|c|}{$57-\alpha /-\alpha$ or $--/ \alpha \alpha$} & 3147 & 2298 & 1.40 \\
\hline Mother & 3.89 & 10.8 & 0.320 & 81 & 27.4 & 34.2 & 17 & \multicolumn{2}{|c|}{$103-\alpha / \alpha \alpha$ or $\alpha \alpha / \alpha a$} & 26885 & 24406 & $6 \quad 1.10$ \\
\hline Father & 5.96 & 14.4 & 0.440 & 74 & 23.7 & 32.6 & 16 & \multicolumn{2}{|c|}{$62-\alpha /-\alpha$ or $--/ \alpha \alpha$} & 1289 & 702 & 21.84 \\
\hline III M-31 & 4.58 & 9.6 & 0.290 & 62 & 20.7 & 33.5 & 13 & \multicolumn{2}{|c|}{$46-\alpha /-\alpha$ or $--/ \alpha \alpha$} & 3848 & 2361 & 1.63 \\
\hline Mother & 4.96 & 10.9 & 0.340 & 66 & 21.6 & 32.7 & 18 & \multicolumn{2}{|c|}{$61-a /-\alpha$ or $--/ a \alpha$} & 2458 & 1359 & 1.81 \\
\hline Father & 5.17 & 13.5 & 0.400 & 76 & 25.7 & 34.1 & 22 & 66 & $-\alpha / \alpha \alpha$ & 1228 & 920 & 1.34 \\
\hline$M-25$ & 5.66 & 11.9 & 0.340 & 60 & 20.6 & 34.8 & 10 & 100 & $-\alpha /-\alpha$ & 3971 & 2739 & 1.45 \\
\hline Mother & 4.41 & 11.9 & 0.345 & 77 & 26.5 & 34.7 & 22 & 93 & $-a / a a$ & 2584 & 2101 & 1.23 \\
\hline Father & 4.96 & 14.4 & 0.435 & 87 & 28.7 & 33.4 & - & - & $-\alpha / \alpha \alpha$ & - & - & - \\
\hline$F-29$ & 5.61 & 13.6 & 0.376 & 67 & 23.8 & 36.4 & 18 & 63 & $-\alpha /-\alpha$ & 2050 & 1363 & 31.50 \\
\hline Mother & 4.64 & 14.5 & 0.403 & 86 & 30.9 & 36.2 & 25 & 88 & $-\alpha / \alpha \alpha$ & 3079 & 2575 & $5 \quad 1.20$ \\
\hline Father & 5.16 & 16.9 & 0.464 & 89 & 32.2 & 36.6 & 32 & 60 & $-\alpha / \dot{\alpha} \alpha$ & 614 & 494 & 1.24 \\
\hline \multicolumn{13}{|c|}{ Ch11dren w1th $\underline{2 z}$ ㅂb $\underline{\text { Bart's }}$ and their parents. } \\
\hline F- 36 & 4.54 & 12.4 & 0.374 & 82 & 26.9 & 33.4 & 20 & 59 & $-\alpha / \alpha \alpha$ & 1370 & 1040 & 1.31 \\
\hline Mother & 4.27 & 12.5 & 0.387 & 90 & 28.8 & 32.3 & 16 & 86 & $-\alpha / \alpha \alpha$ & 4420 & 3240 & 1.36 \\
\hline \multirow{2}{*}{$\begin{array}{l}\text { Father } \\
\text { Brother } \\
\text { (13 yrs) }\end{array}$} & 4.39 & 14.1 & 0.425 & 96 & 31.7 & 33.4 & 28 & 62 & $-\alpha / \alpha \alpha$ & 2510 & 1682 & 1.49 \\
\hline & 4.69 & 11.5 & 0.357 & 75 & 24.2 & 32.4 & 15 & 63 & $-\alpha /-\alpha$ & 4305 & 2359 & 1.82 \\
\hline$F-30$ & 4.85 & 12.4 & 0.377 & 77 & 25.1 & 33.0 & 10 & 48 & $-\alpha / \alpha \alpha$ & 1889 & 1390 & 1.36 \\
\hline Mother & 4.92 & 14.1 & 0.429 & 86 & 28.3 & 33.1 & 33 & 93 & $-\alpha / \alpha \alpha$ & 539 & 408 & 1.32 \\
\hline Father & 4.94 & 14.9 & 0.441 & 88 & 29.6 & 33.9 & 33 & 62 & $-\alpha / \alpha \alpha$ & 2493 & 2067 & 1.20 \\
\hline III $F-24$ & 4.79 & 13.3 & 0.373 & 77 & 27.3 & 35.8 & 21 & 71 & $-\alpha / \alpha \alpha$ & 1269 & 1058 & 1.20 \\
\hline Mother & 4.63 & 14.2 & 0.400 & 87 & 30.1 & 36.3 & 20 & 74 & $-\alpha / \alpha \alpha$ & 2058 & 1634 & 1.26 \\
\hline Father & 4.83 & 17.4 & 0.480 & 98 & 35.6 & 35.6 & 24 & 60 & $-\alpha / \alpha a$ & 1624 & 1203 & 1.35 \\
\hline$M-37$ & 4.34 & 12.7 & 0.350 & 80 & 28.9 & 36.6 & 26 & 54 & $-\alpha / \alpha \alpha$ & 2110 & 1759 & 1.20 \\
\hline Mother & 4.27 & 13.3 & 0.364 & 85 & 30.8 & 36.9 & 33 & 64 & $-a / a \alpha$ & 991 & 787 & 1.26 \\
\hline Father & 5.59 & 17.3 & 0.481 & 85 & 30.5 & 36.2 & 23 & 64 & $-\alpha / \alpha \alpha$ & 1057 & 783 & 1.35 \\
\hline F-29 & 4.24 & 10.9 & 0.337 & 79 & 25.2 & 32.4 & 20 & 59 & $-\alpha / a \alpha$ & 2180 & 1691 & 1.28 \\
\hline Mother & 4.01 & 11.9 & 0.360 & 89 & 29.1 & 33.1 & 21 & 65 & $\alpha \alpha / \alpha \alpha$ & 2777 & 2956 & 0.94 \\
\hline Father & - & - & - & - & - & - & - & - & $-\alpha / \alpha \alpha$ & & & - \\
\hline Children w1 & $\underline{\text { LEt }}$ BD & Bart's. & & & & & & & & & & \\
\hline$F-24$ & 5.13 & 13.1 & 0.380 & 74 & 25.1 & 34.4 & 15 & 84 & $\alpha \alpha / \alpha \alpha$ & 948 & 903 & 1.05 \\
\hline$F-22$ & 4.00 & 12.4 & 0.348 & 86 & 30.5 & 35.8 & 18 & 70 & $\alpha \alpha / \alpha \alpha$ & 1566 & 1820 & 0.86 \\
\hline F-24 & 5.20 & 14.2 & 0.400 & 77 & 27 & 35.5 & 16 & 83 & $\alpha \alpha / \alpha a$ & 4358 & 4230 & 1.03 \\
\hline $\mathrm{F}-21$ & 4.32 & 11.9 & 0.324 & 74 & 27 & 37 & 22 & $77 \alpha \alpha$ & $\alpha / \alpha \alpha$ or $-\alpha / \alpha \alpha$ & 1700 & 1478 & 1.15 \\
\hline$M-24$ & 4.28 & 11.3 & 0.333 & 79 & 26 & 33.3 & 19 & 54 & $-\alpha / \alpha \alpha$ & 2758 & 2184 & 1.26 \\
\hline
\end{tabular}


TABLE III Hematological and Hemoglobin Synthesis Data on Children from Ghana and their Mothers.

\begin{tabular}{|c|c|c|c|c|c|c|c|c|c|c|c|c|c|}
\hline \multirow{2}{*}{ Subject ${ }^{*}$} & \multirow{2}{*}{$\begin{array}{c}\mathrm{RBC} \\
10^{12 / 1}\end{array}$} & \multirow{2}{*}{$\begin{array}{c}\mathrm{Hb} \\
\mathrm{g} / \mathrm{d} 1\end{array}$} & \multirow{2}{*}{$\begin{array}{l}\mathrm{PCV} \\
1 / 1\end{array}$} & \multirow{2}{*}{$\begin{array}{r}\text { MCV } \\
\mathrm{f} 1\end{array}$} & \multirow{2}{*}{$\begin{array}{r}\mathrm{MCH} \\
\mathrm{Pg}\end{array}$} & \multirow{2}{*}{$\begin{array}{l}\text { MCHC } \\
8 / d 1\end{array}$} & \multirow{2}{*}{$\begin{array}{c}\text { Ho } \\
\text { Type }\end{array}$} & \multirow{2}{*}{\multicolumn{2}{|c|}{$\begin{array}{l}\text { Suggested } \\
\text { Genotype }\end{array}$}} & \multirow[b]{2}{*}{$\beta^{S}$ or } & \multicolumn{3}{|c|}{$\frac{\text { HEMOCLOBIN SYNTHESIS }}{\text { Total Count }}$} \\
\hline & & & & & & & & & & & $\beta^{C} \quad \frac{T O}{B}$ & $\frac{a 1}{\alpha}$ & $\frac{\text { ount }}{\text { non- } \alpha / \alpha}$ \\
\hline - Ch11d & 4.65 & 10.6 & 0.355 & 75 & 23 & 30.5 & A & & $-\alpha /-\alpha$ & & 739 & 486 & 1.52 \\
\hline Mother & 4.98 & 13.3 & 0.445 & 89 & 27 & 30 & $\operatorname{AS}(23)$ & & $-\alpha / \alpha \alpha$ & 204 & 442 & 457 & 1.42 \\
\hline II - Ch1ld & 5.03 & 11.1 & - & - & 22.5 & - & $\mathrm{AA}$ & & $-a /-a$ & & 746 & 392 & 1.90 \\
\hline Mother & 3.57 & 10.2 & 0.330 & 92 & 29 & 31.5 & A & & $-\alpha /-a$ & & 579 & 405 & 1.43 \\
\hline III - Child & 4.74 & 10.4 & 0.345 & 72 & 22 & 30.5 & A & $-\alpha /-\alpha$ & or $-\alpha / \alpha \alpha$ & & 1422 & 995 & 1.43 \\
\hline Mother & 4.21 & 11.3 & 0.365 & 86 & 27 & 31.5 & A & $-\alpha / \alpha \alpha$ & or $\alpha a / \alpha a$ & & 2028 & 1946 & 1.04 \\
\hline IV - Child & 5.75 & 10.6 & 0.350 & 60 & 18.5 & 31 & $\mathrm{AC}(30)$ & & $-\alpha / \alpha \alpha$ & 236 & 608 & 608 & 1.39 \\
\hline Mother & 3.75 & 11.4 & 0.365 & 96 & 31 & 32 & & & $\alpha \alpha / \alpha \alpha$ & & 2136 & 2547 & 0.84 \\
\hline$v-$ Ch1ld & 5.31 & 10.9 & 0.370 & 67 & 20.5 & 30.5 & AS (25) & $-\alpha /-\alpha$ & or $-\alpha / \alpha \alpha$ & 295 & 755 & 878 & 1.20 \\
\hline Mother & 4.29 & 12.8 & 0.425 & 98 & 30 & 30.5 & AS (31) & $-\alpha / \alpha \alpha$ & or $\alpha \alpha / \alpha \alpha$ & 768 & 1627 & 2070 & 1.16 \\
\hline VI - Ch11d & 5.36 & 11.1 & 0.370 & 68 & 21 & 31 & AS (23) & & $-\alpha / \alpha \alpha$ & 93 & 320 & 295 & 1.40 \\
\hline Mother & 3.89 & 11.4 & 0.335 & 85 & 30 & 35 & AS (32) & & $\alpha \alpha / \alpha \alpha$ & 345 & 765 & 1275 & 0.87 \\
\hline
\end{tabular}

* The children were 3 to 5 years old at the time of the study.

** Values between parenthesis indicate the percent of the abnormal hemoglobin.

*** Data from Hb synthesis analyses make 1t unllkely that the mothers have the -a/aa genotype; therefore, the chlldren carry a duplicated a chain locus on at least one chromosome and likely have the $-\alpha / a \alpha$ genotype. The low MCV and MCH values are perhaps due to a mild Iron defictency anemla.

TABLE IV Hematological and Hemoglobin Synthesis Data on Adult Controls.

\begin{tabular}{|c|c|c|c|c|c|c|c|c|c|c|c|c|c|c|c|}
\hline $\begin{array}{l}\text { Subject } \\
\text { and Sex }\end{array}$ & $\begin{array}{c}\underset{\mathrm{RBC}}{12} / 1 \\
10^{12} / 1\end{array}$ & $\begin{array}{c}\mathrm{Hb} \\
\mathrm{g} / \mathrm{d} 1\end{array}$ & $\begin{array}{l}\text { PCV } \\
1 / 1\end{array}$ & $\begin{array}{r}\text { MCV } \\
\mathrm{f} 1\end{array}$ & $\begin{array}{r}\mathrm{MCH} \\
\mathrm{PB}\end{array}$ & $\begin{array}{l}\mathrm{MCHC} \\
\mathrm{B} / \mathrm{d} 1\end{array}$ & $\begin{array}{c}\mathrm{Hb} \\
\text { Synthesis } \\
B / a\end{array}$ & $\begin{array}{l}\text { Subject } \\
\text { and Sex }\end{array}$ & $\begin{array}{c}\mathrm{RBC} \\
10^{12} / 1\end{array}$ & $\begin{array}{c}\mathrm{Hb} \\
\mathrm{g} / \mathrm{d} 1\end{array}$ & $\begin{array}{l}\text { PCV M } \\
1 / 1\end{array}$ & $\begin{array}{r}\text { MCV } \\
\text { f1 }\end{array}$ & $\begin{array}{r}\mathrm{MCH} \\
\mathrm{pg}\end{array}$ & $\begin{array}{l}\mathrm{MCHC} \\
\mathrm{g} / \mathrm{d} 1\end{array}$ & $\begin{array}{c}\text { Hb } \\
\text { Synthesis } \\
\beta / \alpha\end{array}$ \\
\hline \multicolumn{8}{|c|}{ Norma1 Caucas1an Adults } & Norma1 & \multicolumn{7}{|c|}{ Black Adults } \\
\hline $1-\mathrm{M}$ & 5.04 & 16.2 & 0.500 & 98 & 31.6 & 32.5 & 1.04 & $1-M$ & 4.73 & 15.1 & 0.434 & 92 & 31.9 & 34.9 & 1.17 \\
\hline $2-F$ & 5.35 & 12.8 & 0.379 & 87 & 29.6 & 34.1 & 1.18 & $2-M$ & 4.21 & 12.5 & 0.361 & 86 & 29.7 & 34.7 & 1.05 \\
\hline $3-M$ & 5.61 & 15.2 & 0.443 & 79 & 27 & 35.0 & 0.92 & $3-M$ & 5.76 & 15.8 & 0.461 & 81 & 27.5 & 34.5 & 1.07 \\
\hline $4-M$ & 4.66 & 14.2 & 0.466 & 85 & 30.7 & 34.7 & 0.88 & $4-M$ & 4.27 & 13.3 & 0.390 & 92 & 31.0 & 34.0 & 1.08 \\
\hline $5-F$ & 3.38 & 10.6 & 0.311 & 92 & 31.5 & 34.2 & 1.11 & $5-F$ & 3.64 & 10.3 & 0.301 & 82 & 28.4 & 34.5 & 1.30 \\
\hline $6-M$ & 4.98 & 15.4 & 0.450 & 90 & 30.9 & 34.0 & 1.05 & $6-F$ & 3.96 & 11.3 & 0.329 & 83 & 28.7 & 34.7 & 1.22 \\
\hline $7-F$ & 4.88 & 15.2 & 0.488 & 88 & 31.1 & 35.3 & 1.11 & $7-M$ & 3.96 & 12.3 & 0.353 & 89 & 31.3 & 35.2 & 1.04 \\
\hline \multirow[t]{2}{*}{$8-F$} & 4.53 & 12.1 & 0.453 & 93 & 26.4 & 29 & 1.01 & $8-F$ & 4.06 & 13.0 & 0.388 & 95 & 32.1 & 33.7 & 1.24 \\
\hline & & & & & & & & $9-F$ & 4.06 & 11.0 & 0.347 & 85 & 27.2 & 32.0 & 1.35 \\
\hline \multicolumn{4}{|c|}{$\alpha$-thalassem1a tralt } & & & & & $10-M$ & 4.63 & 14.2 & 0.404 & 87 & 30.8 & 35.2 & 1.03 \\
\hline $1-M$ & 6.71 & 14.8 & 0.442 & 65 & 21.7 & 33.0 & 1.62 & $11-M$ & 4.86 & 14.6 & 0.405 & 84 & 29.5 & 36.8 & 1.01 \\
\hline $2-F$ & 4.56 & 10.8 & 0.335 & 74 & 23.0 & 32.0 & 1.75 & $12-\mathrm{F}$ & 4.77 & 13.0 & 0.380 & 78 & 27.0 & 35.0 & 0.99 \\
\hline $3-F$ & 4.97 & 11.4 & 0.378 & 75 & 23.0 & 30.4 & 1.69 & $13-M$ & 4.14 & 12.3 & 0.370 & 89 & 30.0 & 34.0 & 0.99 \\
\hline $4-M$ & 5.00 & 11.6 & 0.376 & 74 & 23.3 & 31.0 & 1.87 & $14-F$ & 4.24 & 13.2 & 0.400 & 93 & 31.0 & 34.0 & 1.02 \\
\hline $5-F$ & 4.78 & 11.4 & 0.365 & 76 & 24.0 & 32.0 & 1.33 & & & & & & & & \\
\hline
\end{tabular}

TABLE V Statistical Analyses

\begin{tabular}{|c|c|c|c|c|c|c|c|}
\hline Subject & нь & $\mathrm{RBC}$ & PCV & MCV & MCH & MCHC & $\begin{array}{l}\text { Hemoglobin Synthesis } \\
B / \alpha\end{array}$ \\
\hline \multicolumn{8}{|c|}{ Ch1ldren with $5 \%$ Hb Bart's versus } \\
\hline Children with 22 Hb Bart's & $\begin{array}{l}t=0.891 \\
n=8 \\
P>0.2\end{array}$ & $\begin{array}{l}\mathrm{t}=3.248 \\
\mathrm{n}=8 \\
\mathrm{P}<0.02\end{array}$ & $\begin{array}{l}t=1.812 \\
n=8 \\
p>0.1\end{array}$ & $\begin{array}{l}t=8.95 \\
n=8 \\
P<0.001\end{array}$ & $\begin{array}{l}t=4.994 \\
n=8 \\
P<0.01\end{array}$ & $\begin{array}{l}t=0.811 \\
n=8 \\
P>0.5\end{array}$ & $\begin{array}{l}t=4.595 \\
n=8 \\
p<0.01\end{array}$ \\
\hline Ch1ldren without Hb Bart's & $\begin{array}{l}t=1.215 \\
n=8 \\
P>0.2\end{array}$ & $\begin{array}{l}t=2.407 \\
n=8 \\
P<0.05\end{array}$ & $\begin{array}{l}t=1.263 \\
n=8 \\
P>0.2\end{array}$ & $\begin{array}{l}t=5.45 \\
n=8 \\
P<0.001\end{array}$ & $\begin{array}{l}t=4.67 \\
n=8 \\
P<0.01\end{array}$ & $\begin{array}{l}t=0.938 \\
n=8 \\
P>0.2\end{array}$ & $\begin{array}{l}t=5.606 \\
n=8 \\
P<0.001\end{array}$ \\
\hline Adult a-thal. tralt & $\begin{array}{l}t=0.366 \\
n-8 \\
P>0.5\end{array}$ & $\begin{array}{l}t=0.416 \\
n=8 \\
P>0.5\end{array}$ & $\begin{array}{l}t=2.090 \\
n=8 \\
P>0.5\end{array}$ & $\begin{array}{l}t=3.756 \\
n=8 \\
P<0.01\end{array}$ & $\begin{array}{l}t=1.376 \\
n=8 \\
p>0.2\end{array}$ & $\begin{array}{l}t=3.746 \\
n=8 \\
P<0.001\end{array}$ & $\begin{array}{l}t=1.468 \\
n=8 \\
P>0.1\end{array}$ \\
\hline \multicolumn{8}{|c|}{ Ch1ldren with $2 \%$ Hb Bart's versus } \\
\hline Children without Hb Bart's & $\begin{array}{l}t=0.376 \\
n=8 \\
P>0.5\end{array}$ & $\begin{array}{l}t=0.128 \\
n=8 \\
P>0.5\end{array}$ & $\begin{array}{l}t=0.312 \\
n=8 \\
p>0.5\end{array}$ & $\begin{array}{l}t=0.416 \\
n=8 \\
P>0.5\end{array}$ & $\begin{array}{l}t=0.379 \\
n=8 \\
P>0.5\end{array}$ & $\begin{array}{l}t=0.924 \\
n=8 \\
P>0.2\end{array}$ & $\begin{array}{l}t=2.716 \\
n=8 \\
P<0.05\end{array}$ \\
\hline Adult $\alpha$-tha1. tralt & $\begin{array}{l}t=0.665 \\
n=8 \\
p>0.5\end{array}$ & $\begin{array}{l}t=0.612 \\
n=8 \\
p>0.1\end{array}$ & $\begin{array}{l}t=0.894 \\
n=8 \\
p>0.2\end{array}$ & $\begin{array}{l}t=2.831 \\
n=8 \\
p<0.05\end{array}$ & $\begin{array}{l}t=4.6 \\
n=8 \\
P<0.01\end{array}$ & $\begin{array}{l}t=2.42 .7 \\
n=8 \\
P<0.05\end{array}$ & $\begin{array}{l}t=4.02 \\
n=8 \\
P<0.01\end{array}$ \\
\hline \multicolumn{8}{|c|}{ Parents of Children with $5 \%$ Hb Bart's versus } \\
\hline $\begin{array}{l}\text { Parents of Children with } \\
2 \pi \mathrm{Hb} \text { Bart's }\end{array}$ & $\begin{array}{l}t=1.160 \\
n=17 \\
p>0.2\end{array}$ & $\begin{array}{l}t=1.029 \\
n=17 \\
P>0.2\end{array}$ & $\begin{array}{l}t=1.190 \\
n=17 \\
p>0.2\end{array}$ & $\begin{array}{l}t=3.600 \\
n=17 \\
P<0.01\end{array}$ & $\begin{array}{l}t=2.786 \\
n=17 \\
p<0.02\end{array}$ & $\begin{array}{l}t=0.276 \\
n=17 \\
P>0.5\end{array}$ & $\begin{array}{l}t=0.960 \\
n=16 \\
P>0.2\end{array}$ \\
\hline Adult a-thal. tra1t & $\begin{array}{l}t=1.417 \\
n=13 \\
P>0.1\end{array}$ & $\begin{array}{l}t=0.833 \\
n=13 \\
P>0.2\end{array}$ & $\begin{array}{l}t=0.6 \\
n=13 \\
P>0.5\end{array}$ & $\begin{array}{l}t=1.961 \\
n=13 \\
P>0.05\end{array}$ & $\begin{array}{l}t=2.785 \\
n=13 \\
P<0.02\end{array}$ & $\begin{array}{l}t=3.342 \\
n=13 \\
P<0.01\end{array}$ & $\begin{array}{l}t=3.992 \\
n=12 \\
P>0.05\end{array}$ \\
\hline
\end{tabular}


TABLE V continued

\begin{tabular}{|c|c|c|c|c|c|c|c|}
\hline Subject & $\mathrm{Hb}$ & RBC & PCV & MCV & MCH & MCHC & $\begin{array}{l}\text { Hemoglobin Synthes1s } \\
\qquad / \alpha\end{array}$ \\
\hline Black Adults & $\begin{array}{l}t=0.581 \\
n=22 \\
P>0.5\end{array}$ & $\begin{array}{l}t=2.309 \\
n=22 \\
P<0.02\end{array}$ & $\begin{array}{l}t=0.333 \\
n=22 \\
P>0.5\end{array}$ & $\begin{array}{l}t=3.041 \\
n=22 \\
P<0.01\end{array}$ & $\begin{array}{l}t=2.717 \\
n=22 \\
P<0.02\end{array}$ & $\begin{array}{l}t=1.388 \\
n=22 \\
p>0.1\end{array}$ & $\begin{array}{l}t=3.300 \\
n=21 \\
P<0.01\end{array}$ \\
\hline Caucasian Adults & $\begin{array}{l}t=0.694 \\
n=16 \\
P>0.2\end{array}$ & $\begin{array}{l}t=0.766 \\
n=16 \\
p>0.2\end{array}$ & $\begin{array}{l}t=0.875 \\
n=16 \\
P>0.2\end{array}$ & $\begin{array}{l}t=3.465 \\
n=16 \\
P<0.01\end{array}$ & $\begin{array}{l}\mathrm{t}=2.210 \\
\mathrm{n}=16 \\
\mathrm{P}<0.05\end{array}$ & $\begin{array}{l}t=0.851 \\
n=16 \\
P>0.2\end{array}$ & $\begin{array}{l}t=3.41 \\
n=15 \\
P<0.01\end{array}$ \\
\hline \multicolumn{8}{|c|}{ Parents of Children with $2 X$ Hb Bart's versus } \\
\hline Adult $\alpha$-tha1. trait & $\begin{array}{l}t=2.410 \\
n=12 \\
P<0.05\end{array}$ & $\begin{array}{l}t=2.345 \\
n=12 \\
P<0.05\end{array}$ & $\begin{array}{l}t=1.674 \\
n=12 \\
P>0.1\end{array}$ & $\begin{array}{l}t=6.43 \\
n=12 \\
p<0.001\end{array}$ & $\begin{array}{l}t=7.821 \\
n=12 \\
P<0.001\end{array}$ & $\begin{array}{l}t=3.089 \\
n=12 \\
P<0.01\end{array}$ & $\begin{array}{l}t=3.905 \\
n=12 \\
P<0.2\end{array}$ \\
\hline Black Adults & $\begin{array}{l}t=1.955 \\
n=21 \\
P>0.05\end{array}$ & $\begin{array}{l}t=1.251 \\
n=21 \\
P>0.02\end{array}$ & $\begin{array}{l}t=0.886 \\
n=21 \\
P>0.2\end{array}$ & $\begin{array}{l}t=1.196 \\
n=21 \\
p>0.05\end{array}$ & $\begin{array}{l}t=0.98 \\
n=21 \\
P>0.2\end{array}$ & $\begin{array}{l}t=0.57 \\
n=21 \\
P>0.5\end{array}$ & $\begin{array}{l}t=2.982 \\
n=21 \\
P<0.01\end{array}$ \\
\hline Caucasian Adults & $\begin{array}{l}t=0.392 \\
n=15 \\
p>0.5\end{array}$ & $\begin{array}{l}t=.106 \\
n=15 \\
P>0.5\end{array}$ & $\begin{array}{l}t=0.166 \\
n=15 \\
P>0.5\end{array}$ & $\begin{array}{l}t=0.135 \\
n=1.5 \\
p>0.5\end{array}$ & $\begin{array}{l}t=0.6 \\
n=15 \\
p>0.5\end{array}$ & $\begin{array}{l}t=1.026 \\
n=15 \\
P>0.2\end{array}$ & $\begin{array}{l}t=4.05 \\
n=15 \\
P<0.01\end{array}$ \\
\hline \multicolumn{8}{|c|}{ Adult $\alpha$-thal. tralt versus } \\
\hline Black Adults & $\begin{array}{l}t=1.123 \\
n=17 \\
P>0.2\end{array}$ & $\begin{array}{l}t=2.540 \\
n=17 \\
P<0.05\end{array}$ & $\begin{array}{l}t=0.047 \\
n=17 \\
p>0.5\end{array}$ & $\begin{array}{l}t=5.4 \\
n=17 \\
p<0.001\end{array}$ & $\begin{array}{l}t=8.28 \\
n-17 \\
p<0.001\end{array}$ & $\begin{array}{l}t=4.613 \\
n=17 \\
P<0.001\end{array}$ & $\begin{array}{l}t=7.213 \\
n=17 \\
P<0.001\end{array}$ \\
\hline \multirow[t]{2}{*}{ Caucasian Adults } & $\begin{array}{l}t=1.920 \\
n=11 \\
p>0.05\end{array}$ & $\begin{array}{l}t=1.258 \\
n=11 \\
P>0.2\end{array}$ & $\begin{array}{l}t=1.214 \\
n=11 \\
P>0.2\end{array}$ & $\begin{array}{l}t=5.4 \\
n=11 \\
P<0.001\end{array}$ & $\begin{array}{l}t=7.05 \\
n=11 \\
P<0.001\end{array}$ & $\begin{array}{l}t=1.729 \\
n=11 \\
p>0.1\end{array}$ & $\begin{array}{l}t=7.390 \\
n=11 \\
P<C .001\end{array}$ \\
\hline & $\begin{array}{l}t=1.369 \\
n=20 \\
P>0.1\end{array}$ & $\begin{array}{l}t=1.188 \\
n=20 \\
P>0.2\end{array}$ & $\begin{array}{l}t=1.750 \\
n=20 \\
P>0.05\end{array}$ & $\begin{array}{l}t=0.922 \\
n=20 \\
P>0.2\end{array}$ & $\begin{array}{l}t=0.166 \\
n=20 \\
P>0.3\end{array}$ & $\begin{array}{l}t=1.399 \\
n=20 \\
p>0.2\end{array}$ & $\begin{array}{l}t=1.46 \\
n=20 \\
p>0.1\end{array}$ \\
\hline
\end{tabular}

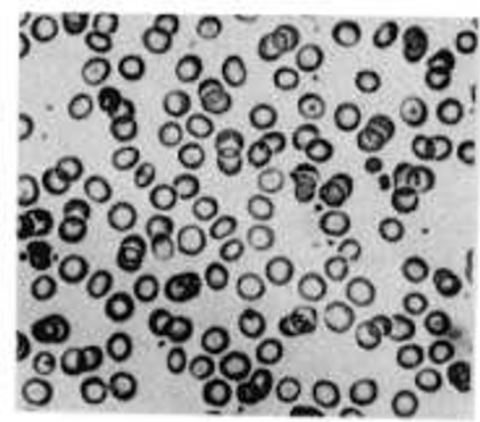

Fig. 1 Peripheral blood smear of a child with a mild microcytosis and hypochromia who had $5 \pi$ Hb Bart's at birth.

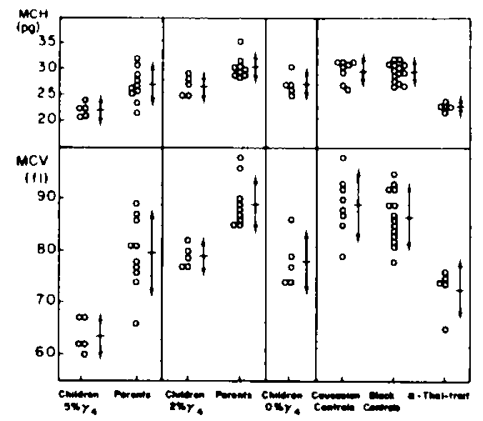

F1g. 2 The MCH and MCV values of the Black chlldren, their parents and the control persons. The mean value for each group and the standard deviation of the mean are also given.

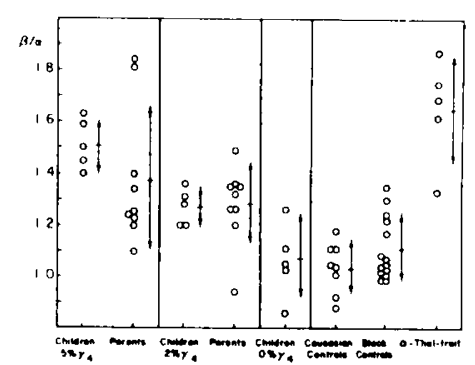

F1g. 3 The globin synthesis data (as B/a ratio) of the Black children, the1r parents and the control persons. The mean value for each roup and the standard deviation of the mean are for each 